\title{
SMES' CREDIT CONDITIONS DURING THE FINANCIAL CRISIS IN EUROPE
}

\author{
Yaseen Ghulam*
}

\begin{abstract}
This study examines the role of firm-specific, macroeconomic, banking and financial environment factors in determining whether they were able to access external finance during the global financial crisis. Heckman's selection approach is used to model the demand and supply of credit in the euro area during and after the financial crisis period. We conclude that since 2011, when the rejection probabilities for external credit applications peaked, the chances of obtaining credit have improved. However, young and small firms are still more likely to have their credit applications rejected. A decrease in government support such as guarantees increases the probability of rejection, as does a reduction in firms' own capital and a worsening credit history. Among the bankspecific factors, an increase in banks' equity capitalization reduces the rejection probability, while an increase in the cost of borrowed funds and a decrease in the competition levels raise the rejection probability. The legal structure to deal with insolvency disputes and the development of the credit information market have a significant bearing on credit availability, as we find that an increase in the time to resolve insolvencies and a reduction in adverse selection problems by credit information sharing increase the credit rejection probabilities.
\end{abstract}

Keywords: credit, financial crisis, supply and demand, small and medium enterprises JEL Classification: G20, G21, G23, G28, L11

\section{Introduction}

In 2013, more than $99 \%$ of the businesses in Europe were small and medium enterprises (SME.) The significance of this economic sector is unquestionable for the economies in Europe, as it creates $75 \%$ of private sector jobs. Notwithstanding the governments' demands, financial intermediaries have been reluctant to lend in the aftermath of the recent financial crisis. Hence, despite unprecedented financial stimuli from various governments and the ECB, there have been invariable worries about a credit crunch for small and medium-sized businesses. This is a serious issue, because the unavailability (or the rationing) of credit for these firms could manifest itself in the form of higher bank rates in comparison with larger firms, which typically have the option of restructuring backed by banks and other creditors. In one study by Anderson and Stallings (2013, p. 21) for the Institute of International Finance (IIF) estimated the closure of more than one hundred thousand small businesses in 2012 in Italy alone. A recent focus on capital

* Yaseen Ghulam, University of Portsmouth, Portsmouth Business School, Economics and Finance Subject Group, Al Yamamah University; Al Yamamah University, Al Qirawan, Riyadh, Saudi Arabia (yaseen.ghulam@port.ac.uk). 
adequacy standards by the banking regulators likewise made it difficult for these businesses to source finance through traditional lending channels during the crisis period.

Recent studies to estimate the impact of the financial crisis on the economy in general, and the corporate sector and financial industry in particular, have frequently been forthcoming (i.e. Kahle and Stulz, 2013; Tagkalakis, 2013; Chodorow-Reich, 2014; Cohen et al., 2014; Hall, 2014), but the damage caused by the financial crisis to smaller firms has been appraised by only a few studies (i.e. Carbo-Valverde et al., 2013; Ogawa and Tanaka, 2013; Vermoesen, 2013; Casey and O'Toole, 2014; Holton et al., 2014). This study endeavours to fill this gap by identifying the crucial firm-specific characteristics, banking and financial market indicators and macroeconomic circumstances that drove the availability of credit to SMEs from banks and other creditors during the financial crisis.

The choice of SMEs to observe the impact of credit crunch and crisis is based on the fact that in a situation when creditors, particularly banks, are forced to repair their balance sheet and increase capital, smaller firms are most likely to be the victim of reduction in lending due to unavailability of proper financial records spreading over many years, less established relationship with banks and lack of viable collateral arrangements. European SMEs in particular are chosen due to the fact that the countries that represents our sample represents a good mix of different stages of economic developments and business activities. The significant role of ECB means that banks in these countries were encouraged to increase their lending to SMEs at almost the same time, and the impact of intervention by the regulator could be assessed better by looking into a number of countries over an extended time period.

\section{Determinants of Demand and Supply of SMEs Finance: Review of Literature}

A good number of studies have looked at the factors that contribute towards decision making process of banks and other financial institutions in approving of loan applications by SMEs as well as subsequent credit performance in terms of payments on time. Since the start of the financial crisis in the USA and other European countries, the number of studies has been growing, due to the role of these enterprises in employment generation and the fear of widespread unemployment if these firms are deprived of finance over an extended period of time. The push by the ECB to help ease the situation has also kept the issue alive. Some of these studies have relied on the cross sectional surveys as ours, while some others have used loan performance data supplied by credit bureaus and rating agencies to address the issue of how to separate demand and supply factors. In the following, we discuss the main outcomes from some selected influential empirical studies published in well reputed journals since 2006 in a chronological order.

Beck and Demirguc-Kunt (2006) present the survey of recent research on access to finance and try to explain not so clear evidence of significant contribution of SMEs activity in economic growth in particular cross-country studies. The authors concluded that SMEs in a number of countries face hurdles in obtaining external finance affecting their growth and this could be one of the reasons of an unclear role for smaller size firms 
in promoting economic growth. Interestingly, authors suggested that "systems of credit information sharing and a more competitive banking structure could help facilitate the greater access to external finance by small opaque firms". Shen et al. (2009) evaluated the SMEs finance activity in China. The authors find that bank size measured by asset is a less important factor in determining the acceptance of loan application by a small and medium size firm. In fact some of the relevant bank specific factors in regard to approving credit for a SME include the autonomy of local branch managers in decision making, incentive schemes, and the enforcement of contracts.

Similarly, Canales and Nanda (2012) study the impact of organizational structure of banks on small businesses lending. They concluded that bank managers with local market power and operating under decentralized organizational structure are more likely to extend loans compared to those operating in a less competitive environment. The authors concluded that the local banking environment is very important in determining bankers' willingness to extend credit to smaller businesses, rather than just decentralized banking organizational structure only. Mac and Bhaird (2013) investigated the factors which influence demand and supply conditions in regard to SMEs external finance. The authors concluded that factors such as firm ownership, asset structure, age and size influence the demand for external credit while financially distressed firms suffer most in obtaining external credit during the period of financial crisis and related credit crunches. One interesting result of the study is that once they have failed to secure a loan, firms are less likely to be discouraged and would apply gain to secure external loans.

Beck et al. (2013) explore the relationship between lending institutions financial structure and firms' access to finance from different types of financial institutions. The study concluded that in a situation when banks have market dominance, SMEs use of external finance gets reduced, irrespective of size. Specialized institutions are helping in extending credit to SMEs in developing countries. The study further concluded that contrary to general perception, there is no empirical evidence to support that smaller-size banks extend more credit to SMEs. Modina and Pietrovito (2014) looked at the determinants of defaults for the Italian SMEs financing using a unique data provided by credit information bureau. The author's findings suggest the importance of capital structure of the smaller and mediumsize firm. The other important factor in this regard is the terms of loan in particular the cost of borrowed funds. The implication of this finding is that lending institutions would be reluctant to lend to those firms with less equity in the financial structure, unreliable sources of finance, profitability, current financial issues, which all would lead to higher interest cost and subsequent defaults. Interestingly, the authors suggest that economic variables are less relevant than firm-specific factors such as capital structure in forcing defaults and missed payments.

Holton et al. (2014) investigated the demand and supply conditions in euro area and find the strong impact of real economy on both demand and supply of external credit of the European SMEs. Weak economies not only reduce demand for credit by these firms, but also increase rejections rates by the lenders as well as tightening of terms and conditions attached to loans extended to SMEs. Interestingly, worsening financial conditions have 
a significant impact on credit supply, but not demand by SMEs. An increase in private debt levels in the economy also has a strong negative impact on chances of obtaining external credit by SMEs. Ryan et al. (2014) looked at the role of lending institutions market power on financing decisions in relation to requests from SMEs. The major finding of the study is that presence of a strong market power of banks exacerbates credit constraints of the SMEs. But interestingly, the impact of these constraints varies across different firm sizes and opacity levels. This negative impact of gaining of market power on the part of banks on SMEs credit availability varies depending on economic system in terms of 'market' or 'bank' dependent. The study concluded that banks exercise of market power is stronger in a bank-dependent economy.

A brief review of the selected studies above clearly indicates that financial structure, profitability, local market competitive conditions of the lending institutions are some of the important factors in determining the availability of external credit to SMEs. Economic conditions including indebtedness of the local population (businesses/individuals) also has a strong influence. Firm's specific factors, such as age, size, financial condition, autonomy, and a number of other factors, are also important in determining the demand for external credit and subsequent outcome in terms of approval or rejection on the part of lending institutions. In the following, we discuss our chosen methodology to model demand and supply of external finance by utilizing the variables discussed above alongside a number of other factors deemed relevant in this regard.

\section{Methodology and Data}

We model firms' external Credit (C) supply and demand using a two-step Heckman probit selection equation method, in which the decision to apply for credit (demand) and the propensity of credit application acceptance (supply) are determined sequentially and jointly. The demand for credit is determined by a dummy variable, which is equal to one when a firm applied for bank loans, trade credit or other external finance. The rejection of the supply of loan is more of an issue; hence we construct this indicator by creating a dummy variable equal to one if a firm applied for credit and was refused, was offered credit but refused it due to the high cost or only received a limited part of it (less than 75\%). The rejection propensity of the credit application of firm $i$ is modelled by the following latent function:

$$
C_{i}^{*}=X_{i} \beta+e_{1 \mathrm{i}}(\text { Credit rejection equation })
$$

where $\beta$ is a vector of parameters to be estimated and $X_{i}$ is a vector of independent variables that affects credit supply rejection. The unobserved characteristics of firms are captured by a random variable $e_{1 i}$ with distribution of $e_{1 i} \sim \mathrm{N}(0, \sigma)$. The latent credit supply rejection propensity is represented by a binary outcome: [a] either the firm obtains credit $\left(C_{i}^{*}>0\right)$ and consequently $C_{i}^{*}=1$ or [b] the credit application is rejected $\left(C_{i}^{*}=0\right)$. Obviously, the above binary outcome is only observed if the firm has actually applied previously for credit. That is, if $[\mathrm{c}]$ : 


$$
Z_{i} \gamma+e_{2 i}>0 \text { (credit demand/selection equation) }
$$

Where $\gamma$ is a vector of parameters to be estimated and $Z_{i}$ is a vector of independent variables that affects the decision to apply for credit. In the above, similar to Equation $1, e_{2 i}$ is another random variable with $e_{2 i} \sim \mathrm{N}(0,1)$ that accommodates unobserved firms' characteristics affecting application decisions. Following some of the recent studies in this area, such as Beck et al. (2008), Ivashina and Scharfstein (2010), Artola and Genre (2011), Jimenez et al. (2012), Ferrando and Mulier (2013) and Holton et al. (2014), the $X$ and $Z$ vectors are identified with firm-specific variables such as firm size, organizational structure (autonomous), industry affiliation, turnover, age, owner's gender, trend in profitability, fixed investment, inventories and working capital, internal funds, margins, capital position, leverage and credit history.

More specifically, we start with firm-specific variables which could have an impact on demand and/or supply of external credit. These include firm size, industry affiliation, financial autonomy, age, and gender of the owner. In an effort to observe the impact of firm size, we include two indicators and these include the number of employees and the value of gross sale. Three dummy variables are used for each indicators, while fourth is used as a reference category. The dummy variables to represent size approximated by employees include firm employs 10-49 (small), 50-249 (medium) and 250+ (large) employees. The firm employing less than ten employees (very small) is a reference category. Similarly, another variable to resent size of the firms also is represented by three dummy variables including sale turnover of 2-10 million euros (small), 10-50 (medium) and 50+ (large). Firm's turnover less than 10 million is a reference category in this regard. We include both indicators (number of employees and sale) due to special economic conditions prevailing during a crisis or immediately after a crisis period. The firm could have a significant number of employees but be unable to utilize them due to depressed demand of its product. Authors such as Beck et al. (2006), Brown et al. (2011), Albareto and Russo (2012) and Psillaki and Daskalakis (2009) suggested a negative relation between size and of the firm.

The firm's affiliation with a specific industry could have significant implications for the demand and supply of external credit. In particular after many years during and after the crisis, construction industry activity remained subdued in Europe due to a depressed demand for housing. We include three important industries in our empirical model that are represented by three dummy variables. These include construction, manufacturing and wholesale/retail. Other industries affiliation is used as a reference category. The firm's accumulation of experience and learning is approximated by age. Three dummy variables are used to represent different age categories. These include relatively new ( $2-5$ years age), experienced (5-10 years) and highly experienced (10+ years). The age category of less than 2 years is used as a reference category. Following empirical literature, two other firmspecific variables are included such as a dummy variable to resent financial autonomy of the firm and second, a dummy variable for a female headed firm. Financially autonomous firms are likely to take decision independently in terms of either to apply for external credit and when. Financial independence would also impact decisions in regard to utilizing alternative sources of finance as well as working capital, product design and pricing, etc. 
Similarly, in some empirical studies, it has been reported that female headed enterprises are more likely to be constrained of external credit. Our study tests these predictions too subsequently.

A number of variables to represent firm's current performance in terms pf profitability, capital, and stock of debt are included, which could have significant implications for both demand and supply of external credit. The selection of these variables is based on the existing empirical literature in this area nonetheless. We include two dummy variables to represent firm's profitability in the last six months. Two of the dummy variables to represent firm profit performance include firm's profit in the last six months have deteriorated or remained constant. Similarly, two dummy variables in relation to firms own capital position include firm's capital in the last six months have deteriorated or remained constant. Lastly, a firm's debt situation is approximated by debt to income ratio. We include single dummy variable if debt/income ratio has increased in the last six months.

The next set of firm-specific variables includes firm's perception about future prospects, the provision of public (government) support in terms of guarantees, future economic prospects and banks' willingness to lend. Starting with a firm specific outlook with respect to sales and profitability, we include two dummy variables. These include outlook remained constant and deteriorated. Two dummy variables to represent firm perception about access to financial support including guarantees from government. Again we suppose that public perception remained constant and decreased. Next we add two dummy variables in regard of firm perception of general outlook of the economy and banks willingness to lend to small size businesses. More specifically, these show that general economic outlook worsened and banks willingness to lend worsened. Lastly, we include a dummy variable about enterprise perception in regard to its credit history. We code this variable equal to one if firm perceive that its credit history has not changed or deteriorated in the last six months.

In addition to above mentioned firm's specific factors, we also included some variables, which are more relevant to demands for external funds. Firms were asked to pick one of the options in regard to their need for external credit due to a number of reasons. Some of these reasons to model demand for external debt includes: the firm's need for external funds increased due to: fixed investment, inventories and working capital, internal funds or mark-up has decreased in the last six months. We use one dummy variable for each of these four reasons in our empirical model.

Theoretical literature on monetary transmission and the credit channel has mainly focussed on two channels. Holton et al. (2014) explained that "the credit channel comprises the bank lending channel and the balance sheet channel which deal with the impact of banks' and borrowers' balance sheets, respectively, on the supply of credit'. A good overview in regard to the bank lending channel is provided by Peek and Rosengren (1995) who discuss the interactions between banking conditions and credit supply to firms. Mishkin (1995), Bernanke and Gertler (1995) and Beck et al. (2008) highlighted the importance of banking channels for the supply of credit due to 'asymmetric information' in the case of SMEs finance. Following this, we combine firm-related indicators (balance sheet and others) mentioned above with country and year specific average banking industry 
variables. These include bank capitalization measured by equity/total assets, loan quality approximated by two variables including net charge-off/net income and impaired loans/ gross loans, liquidity shock measured by interbank ratio, profitability shown by return on equity, industry competition measured by total assets based Herfindahl index, loans growth, and interest paid and charged on loans measured by price of borrowed funds (deposits and interbank borrowing) and average interest rate charged on loans to customers and banks.

Following Beck et al. (2006) and Holton et al. (2014), country specific macroeconomic conditions, financial market development and institutional quality that could have significant impact on loans application rejection or acceptance include government debt/ GDP, GDP growth rate, private debt/GDP, GDP per capita and government bond yield. In addition to the above mentioned variables, our empirical model also includes variables related to the financial market and legal structure that helps in screening bad customers as well as enforcing the loan contracts. Two of specific variables in this regard include time to resolve insolvencies (in years), and credit related information asymmetry proxy measured by the credit depth of information index. The credit information index measures rules, regulation and actual practices affecting the scope, coverage, and accessibility of credit information related to individuals or businesses available through either a credit registry or a credit bureau. The index values vary between ' 0 ' (very low coverage or credit information asymmetry) to 8 (high coverage and well documented credit information flow). Country fixed effects and calendar year effects are also included to accommodate countryand time-specific heterogeneity.

The firm-specific variables are derived from the cross-section surveys "Survey on the Access to Finance of SMEs in the Euro Area (SAFE)" collected biannually by the European Central Bank (ECB) between first six months of 2009 and 2013 ${ }^{1}$. Banking and other non-firm data are extracted from Bankscope and the World Development Indicators (WDIs).

Table 1 below displays the descriptive statistics of all the variables used in modelling the demand and supply of external credit of European SMEs. More importantly, for a group of variables representing financial/banking markets, legal structure and economic activity/cycle indicators, the difference between a lower value and higher indicates a large variation in the competition conditions, credit cycles, price of funds, time to resolve insolvencies, GDP growth rates and other macroeconomic conditions across European countries. This is expected due to the fact that our sample covers a 5-year period and 18 countries with more than 8,000 banks. We exploit this heterogeneity in our sample in estimating the conditional application rejection probabilities and building the scenarios.

For questionnaire and data detail, see https:/www.ecb.europa.eu/stats/money/surveys/sme/html/ index.en.html 
Table 1 | Descriptive Statistics of Variables Used in Demand and Supply of SMEs External Finance (2009-2013)

\begin{tabular}{|c|c|c|c|c|}
\hline Variable & Mean & S. Dev. & Min & Max \\
\hline Supply of external finance (dependent variable $=1$ if yes) (d) & 0.099 & 0.299 & 0.000 & 1.000 \\
\hline Demand of external finance (dependent variable $=1$ if applied) (d) & 0.443 & 0.497 & 0.000 & 1.000 \\
\hline Enterprise number of employees - 10-49 (d) & 0.333 & 0.471 & 0.000 & 1.000 \\
\hline Enterprise number of employees - 50-249 (d) & 0.254 & 0.435 & 0.000 & 1.000 \\
\hline Enterprise number of employees - $250+(\mathrm{d})$ & 0.077 & 0.267 & 0.000 & 1.000 \\
\hline Enterprise financial autonomy - autonomous (d) & 0.868 & 0.339 & 0.000 & 1.000 \\
\hline Enterprise industry affiliation - construction (d) & 0.100 & 0.301 & 0.000 & 1.000 \\
\hline Enterprise industry affiliation - manufacturing (d) & 0.255 & 0.436 & 0.000 & 1.000 \\
\hline Enterprise industry affiliation - wholesale/retail (d) & 0.339 & 0.473 & 0.000 & 1.000 \\
\hline Enterprise turnover - 2-10 million Euro (d) & 0.259 & 0.438 & 0.000 & 1.000 \\
\hline Enterprise turnover - 10-50 million Euro (d) & 0.167 & 0.373 & 0.000 & 1.000 \\
\hline Enterprise turnover - 50+ million Euro (d) & 0.076 & 0.265 & 0.000 & 1.000 \\
\hline Enterprise age -10 years $+(\mathrm{d})$ & 0.132 & 0.338 & 0.000 & 1.000 \\
\hline Enterprise age - 5-10 years (d) & 0.072 & 0.259 & 0.000 & 1.000 \\
\hline Enterprise age - 2-5 years (d) & 0.021 & 0.143 & 0.000 & 1.000 \\
\hline Enterprise headed by - female (d) & 0.113 & 0.316 & 0.000 & 1.000 \\
\hline Enterprise performance - profit- $\leftrightarrow$ (d) & 0.269 & 0.444 & 0.000 & 1.000 \\
\hline Enterprise performance - profit $\downarrow$ (d) & 0.474 & 0.499 & 0.000 & 1.000 \\
\hline Enterprise performance - own capital $\leftrightarrow$ (d) & 0.544 & 0.498 & 0.000 & 1.000 \\
\hline Enterprise performance - own capital $\downarrow$ (d) & 0.204 & 0.403 & 0.000 & 1.000 \\
\hline Enterprise performance - debt/assets Ratio $\uparrow(\mathrm{d})$ & 0.207 & 0.405 & 0.000 & 1.000 \\
\hline Enterprise perception about - outlook $\leftrightarrow$ (d) & 0.463 & 0.499 & 0.000 & 1.000 \\
\hline Enterprise perception about - outlook $\downarrow$ (d) & 0.294 & 0.455 & 0.000 & 1.000 \\
\hline Enterprise perception about - public support $\leftrightarrow$ (d) & 0.277 & 0.448 & 0.000 & 1.000 \\
\hline Enterprise perception about - public support $\downarrow$ (d) & 0.218 & 0.413 & 0.000 & 1.000 \\
\hline Enterprise perception about - credit history $\leftrightarrow / \downarrow$ (d) & 0.750 & 0.433 & 0.000 & 1.000 \\
\hline Enterprise perception about - general economic outlook (d) worsened (d) & 0.828 & 0.377 & 0.000 & 1.000 \\
\hline Enterprise perception about - banks willingness to lend (d) worsened (d) & 0.671 & 0.470 & 0.000 & 1.000 \\
\hline Firm need for EF increased due to fixed investment (d) & 0.165 & 0.372 & 0.000 & 1.000 \\
\hline Firm need for EF increased due to invent. \& working cap. (d) capital (d) & 0.204 & 0.403 & 0.000 & 1.000 \\
\hline Firm needs for EF increased due to internal funds (d) & 0.152 & 0.360 & 0.000 & 1.000 \\
\hline Firm markup decreased $(\mathrm{d})$ & 0.487 & 0.500 & 0.000 & 1.000 \\
\hline Economic conditions - government debt/GDP & 85.907 & 33.819 & 0.000 & 219.500 \\
\hline Economic conditions - GDP growth & -0.618 & 3.008 & -9.625 & 12.035 \\
\hline Economic conditions - private debt/GDP & 192.791 & 71.859 & 69.850 & 500.253 \\
\hline Economic conditions - GDP per capita & $37,175.360$ & $9,816.925$ & $13,827.360$ & $111,813.000$ \\
\hline Economic conditions - government bond yield & 4.609 & 3.411 & 1.360 & 25.070 \\
\hline Banking industry - equity/total assets & 8.208 & 1.501 & 4.390 & 19.310 \\
\hline Banking industry - net charge-off/net income & 3.486 & 31.241 & -67.740 & 130.610 \\
\hline Banking industry - impaired loans/gross loans & 6.387 & 4.797 & 0.000 & 30.680 \\
\hline Banking industry - interbank ratio & 65.004 & 31.645 & 15.940 & 175.470 \\
\hline Banking industry - Herfindahl index & 0.108 & 0.062 & 0.050 & 0.482 \\
\hline Banking industry - loans growth & 0.470 & 4.975 & -11.051 & 14.804 \\
\hline Banking industry - return on equity & 3.348 & 6.724 & -50.820 & 27.680 \\
\hline Banking industry - price of borrowed funds & 2.308 & 0.780 & 0.764 & 5.568 \\
\hline Banking industry - average interest rate charged & 4.735 & 0.953 & 2.211 & 8.324 \\
\hline Enforcement of contracts - time to resolve insolvency & 1.505 & 0.574 & 0.000 & 4.000 \\
\hline Information asymmetry - credit depth of information index & 4.867 & 0.869 & 0.000 & 6.000 \\
\hline
\end{tabular}

Source: Authors 


\section{Results}

Equation 1 and 2 are jointly estimated using a STATA Heckman probit model routine. We first jointly estimate the application and rejection propensities; subsequently these estimates are used to calculate the marginal effects and conditional probabilities of credit application rejections. Table 2 shows the predicted conditional probability of rejection by country. By excluding those countries for which a reasonable number of observations is not available in the sample, we observe that SMEs operating in Cyprus, Belgium, France, Ireland and the Netherlands face a high risk of loan application rejection (followed by Finland and Italy). Interestingly, for almost all countries, a peak in rejection occurs in 2011 and the first half of 2012. The rejection probabilities since then have fallen significantly and were notably lower in first six months of $2013\left(2013 \mathrm{~s}_{1}\right)$ compared with the overall average for almost all countries. The marginal effects estimates presented and discussed below also confirms these results where rejection probabilities peaked during 2011 and then started declining.

Table 2 | Conditional Credit Applications Rejection Probabilities of Selected Countries SME's

\begin{tabular}{|c|c|c|c|c|c|c|c|c|c|c|}
\hline & $\begin{array}{c}2009 \\
s_{1}\end{array}$ & $\begin{array}{c}2009 \\
s_{2}\end{array}$ & $\begin{array}{c}2010 \\
s_{1}\end{array}$ & $\begin{array}{c}2010 \\
s_{2}\end{array}$ & $\begin{array}{c}2011 \\
s_{1}\end{array}$ & $\begin{array}{c}2011 \\
s_{2}\end{array}$ & $\begin{array}{c}2012 \\
s_{1}\end{array}$ & $\begin{array}{c}2012 \\
s_{2}\end{array}$ & $\begin{array}{c}2013 \\
s_{1}\end{array}$ & Average \\
\hline Germany & 0.053 & 0.061 & 0.114 & 0.095 & 0.146 & 0.147 & 0.136 & 0.117 & 0.071 & 0.104 \\
\hline France & 0.168 & 0.184 & 0.284 & 0.250 & 0.335 & 0.336 & 0.318 & 0.285 & 0.201 & 0.262 \\
\hline Belgium & 0.187 & 0.205 & 0.312 & 0.277 & 0.366 & 0.368 & 0.349 & 0.316 & 0.225 & 0.289 \\
\hline Finland & 0.118 & 0.131 & 0.218 & 0.189 & 0.265 & 0.267 & 0.251 & 0.222 & 0.148 & 0.201 \\
\hline Netherland & 0.171 & 0.189 & 0.297 & 0.262 & 0.352 & 0.355 & 0.336 & 0.304 & 0.213 & 0.275 \\
\hline Spain & 0.083 & 0.093 & 0.160 & 0.137 & 0.199 & 0.200 & 0.186 & 0.161 & 0.104 & 0.147 \\
\hline Italy & 0.122 & 0.135 & 0.216 & 0.188 & 0.261 & 0.262 & 0.246 & 0.217 & 0.147 & 0.199 \\
\hline Cyprus & 0.338 & 0.361 & 0.484 & 0.444 & 0.541 & 0.541 & 0.521 & 0.483 & 0.380 & 0.455 \\
\hline Greece & 0.053 & 0.060 & 0.112 & 0.094 & 0.143 & 0.144 & 0.133 & 0.114 & 0.069 & 0.102 \\
\hline Ireland & 0.174 & 0.190 & 0.289 & 0.256 & 0.340 & 0.341 & 0.323 & 0.289 & 0.206 & 0.268 \\
\hline Portugal & 0.018 & 0.021 & 0.046 & 0.037 & 0.063 & 0.064 & 0.058 & 0.048 & 0.025 & 0.042 \\
\hline $\begin{array}{l}\text { Austria / } \\
\text { Estonia / } \\
\text { Slovakia / } \\
\text { Slovenia }\end{array}$ & 0.056 & 0.064 & 0.119 & 0.100 & 0.151 & 0.153 & 0.141 & 0.122 & 0.074 & 0.109 \\
\hline
\end{tabular}

Notes: subscript $\mathrm{s}_{1}$ and $\mathrm{s}_{2}$ attached to years indicates first or second part of the year.

Source: Authors

In an effort to observe the impact of each included variable in our credit rejection model (Equation 1) and demand approximated by application (Equation 2), we estimated marginal 
effect estimates of each variable and present them in Table 3. Given the objective of study, we discuss marginal effects related to rejection equation only. Table 3 and Figure 1 show that an increase in enterprise size reduces the probability of rejection of credit application. This is true of all of the survey periods. Young and small enterprises are more likely to have their loan supply constrained. Excluding the exceptional case of very small firms, the differences in the rejection probabilities for other sizes is not noticeable. This finding is also reflected in the turnover marginal-effects coefficients, whereby firms with a turnover of 10 million euros or more have roughly a 4\% lower chance of credit application rejection. Beck et al. (2008), Artola and Genre (2011) and Holton et al. (2014) also find that larger and older firms face the lowest risk of having loan applications rejected.

Figure 1 | Predicted Conditional Probability of Credit Rejection (by enterprise size)

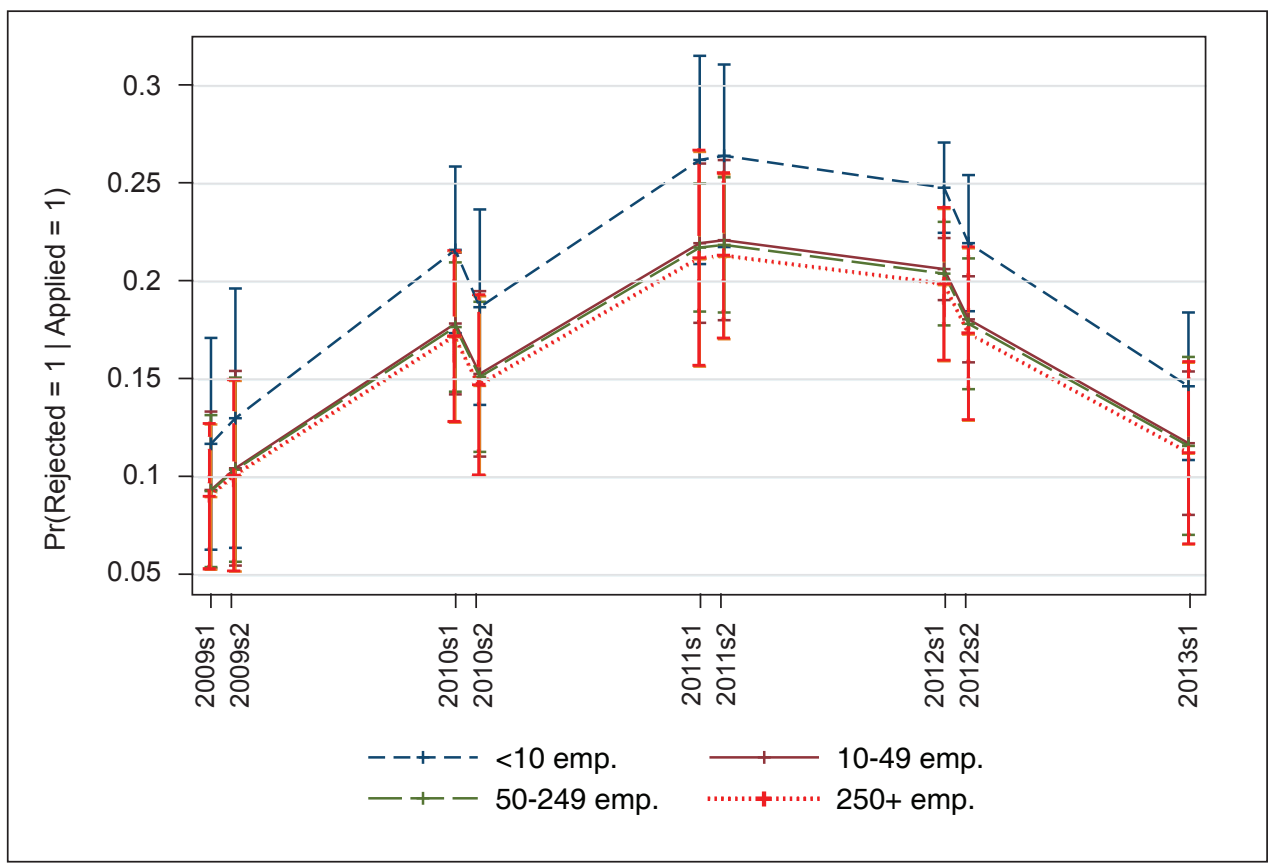

Source: Authors' calculation. Vertical bar above represent lower and upper confidence interval.

Firms in the construction business are also more likely to have their credit applications rejected. Firms that are engaged in manufacturing activity, however, have a slight edge, with a marginally higher probability of the acceptance of their application. Female-headed enterprises have a slightly lower probability of rejection. Interestingly, financial autonomy has no statistically significant bearing on rejection chances.

The next set of variables includes firms' performance related factors. Firm performance is measured in terms of profitability, capitalization and indebtedness. Holton et al. (2014) conclude that firms that reported a fall in profits or had poor prospects in the upcoming 
months were likely to face reductions in credit availability. Our marginal-effects estimates confirm the fact that as profits decrease, the probability of rejection increases (although the increase in rejection probability is inconsequential and statistically insignificant, which is similar to Martínez-Sola et al.'s (2014) study of Spanish SMEs, in which they find no empirical relation between trade credit finance and profitability). According to Jimenez et al. (2012), a sign of borrowers' creditworthiness is captured by their net worth. Since the crisis, the net worth of most SMEs has been affected by a debt overhang, so even firms with profitable investment opportunities have been unable to fund those investments (Holton et al., 2014). Our estimates show that debt overhang leads to increased rejection rates by approximately $2 \%$, while a reduction in the firm's own capital or worsening credit history increases the rejection probability by $6 \%$, as creditors become wary of providing credit to SMEs that are highly leveraged and/or lack collateral.

The lodging of external loan application as well as subsequent acceptance could depend on firm perceptions about outlook with respect to its sales and profitability, public support in terms of guarantees, credit history, general economic outlook, banks willingness to lend and increasing dependence on external finance. The next set of regression coefficients shows the application and rejection outcomes with respect to these perception variables. In terms of the future outlook of profitability and sales, during times of economic uncertainty, stagnancy would indeed be a welcome scenario for firms and creditors, as the results in Table 3 show that a stagnant outlook reduces the probability of credit rejection. Similarly, reduced banks willingness to lend to businesses as well as worsening credit histories also increase the chances of loan application rejection. Lastly, an increase in demand for external finance due to investment, working capital requirements and reduction in internal funds also increase the chances of loan application rejection. These could in some cases be inherent issues in the running of businesses or in some others, there could be a genuine increase in demand for external funds due to rising investment opportunities.

Table 3 also displays the impact of bank-specific, market and economic conditions variables on the probability of SME credit rejection. Starting with the economic conditions variables, the level of economic development is an indicator that could explain the differences in the credit approval mechanism across different European countries. Cole and Dietrich (2013) using the World Bank's "Enterprise Survey" find that firms in countries with a higher per capita GDP are less likely to be denied credit. We would also expect a similar negative relation between rejection probability and economic development. Our marginal-effects estimates also endorse this and show that, for each US\$1,000 increase in per capita GDP, the probability of credit rejection decreases by $0.8 \%$. GDP growth rates, private debt and government borrowing, however, do not have a statistically significant impact on loan application rejection. One of the surprising results in this regard is the impact of government bond yields. One would expect that rising yield in T-bill would indicate the trouble in government finances and resulting increase in uncertainties leading to more rejections. But our regression coefficient shows otherwise. An increase in yield is linked with a decrease in rejection probability. One of the possible reasons could be that an increase in T-bills would result in crowding out of funds available for lending to private businesses leading to more rejections. 
Table 3 | Selected Average Marginal Effects of SME's External Credit (dependent variables are applied and applied but rejected)

\begin{tabular}{|c|c|c|}
\hline Variables & Rejected & Applied \\
\hline Enterprise number of employees - 10-49 (d) & $-0.03250^{* * *}$ & $0.06508^{* * *}$ \\
\hline Enterprise number of employees - 50-249 (d) & $-0.03410^{* * *}$ & $0.08844^{* * *}$ \\
\hline Enterprise number of employees - $250+(d)$ & $-0.03958^{* *}$ & $0.10240 * * *$ \\
\hline Enterprise financial autonomy - autonomous (d) & 0.01073 & $0.08648^{* * *}$ \\
\hline Enterprise industry affiliation - construction (d) & $0.02325^{* * *}$ & 0.00356 \\
\hline Enterprise industry affiliation - manufacturing (d) & $-0.01141^{* *}$ & -0.00975 \\
\hline Enterprise industry affiliation - wholesale/retail (d) & -0.00980 & $-0.02201^{* *}$ \\
\hline Enterprise turnover - 2-10 million Euro (d) & -0.00922 & $0.04104^{* * *}$ \\
\hline Enterprise turnover - 10-50 million Euro (d) & $-0.04442^{* * *}$ & $0.03972^{* * *}$ \\
\hline Enterprise turnover - 50+ million Euro (d) & $-0.04275^{* *}$ & $0.04059 * * *$ \\
\hline Enterprise age -10 years $+(\mathrm{d})$ & $0.02752^{* * *}$ & 0.00984 \\
\hline Enterprise age $-5-10$ years $(\mathrm{d})$ & $0.04097^{* * *}$ & 0.00851 \\
\hline Enterprise age - $2-5$ years (d) & $0.05305^{* * *}$ & $0.05057^{* * *}$ \\
\hline Enterprise headed by - female (d) & $-0.01389^{* *}$ & $-0.02457^{* * *}$ \\
\hline Enterprise performance - profit- $\leftrightarrow$ (d) & -0.00563 & -0.00874 \\
\hline Enterprise performance - profit $\downarrow$ (d) & 0.00867 & $-0.01091^{*}$ \\
\hline Enterprise performance - own capital $\leftrightarrow$ (d) & -0.00437 & $-0.00771^{*}$ \\
\hline Enterprise performance - own capital $\downarrow$ (d) & $0.06051^{* * *}$ & -0.00291 \\
\hline Enterprise performance - debt/assets ratio $\uparrow(\mathrm{d})$ & $0.02365^{* * *}$ & $0.13500^{* * *}$ \\
\hline Enterprise perception about - outlook $\leftrightarrow$ (d) & $-0.04009^{* * *}$ & $-0.04893^{* * *}$ \\
\hline Enterprise perception about - outlook $\downarrow$ (d) & -0.00374 & -0.00763 \\
\hline Enterprise perception about - public support $\leftrightarrow$ (d) & 0.00308 & -0.01313 \\
\hline Enterprise perception about - public support $\downarrow$ (d) & $0.08993 * * *$ & $0.02605^{* * *}$ \\
\hline Enterprise perception about - credit history $\leftrightarrow / \downarrow$ (d) & $0.01577^{* * *}$ & $-0.04212^{* * *}$ \\
\hline Enterprise perception about - general economic outlook worsened (d) & -0.00122 & -0.00286 \\
\hline Enterprise perception about - banks willingness to lend worsened (d) & $0.07042^{* * *}$ & $0.16440^{* * *}$ \\
\hline Firm need for EF increased due to fixed investment (d) & $0.06708^{* * *}$ & $0.15660^{* * *}$ \\
\hline Firm need for EF increased due to inventories \& working capital (d) & $0.05856^{* * *}$ & $0.13670^{* * *}$ \\
\hline Firm needs for EF increased due to internal funds (d) & $0.02823^{* * *}$ & $0.06590^{* * *}$ \\
\hline Firm markup decreased (d) & 0.00055 & 0.00129 \\
\hline Economic conditions - GDP growth & -0.00460 & -0.00175 \\
\hline Economic conditions - private debt/GDP & 0.00013 & $8.723 e-05$ \\
\hline Economic conditions - government bond yield & $-0.00282^{* * *}$ & $-0.00658^{* * *}$ \\
\hline Economic conditions - government debt/GDP & 0.00053 & - \\
\hline Economic conditions - GDP per capita & $-7.242 \mathrm{e}-06^{* * *}$ & - \\
\hline Banking industry - equity/total assets & $-0.01303^{* *}$ & - \\
\hline Banking industry - net charge-off/net income & $1.959 \mathrm{e}-05$ & - \\
\hline Banking industry - impaired loans/gross loans & $-0.00369 * * *$ & - \\
\hline Banking industry - interbank ratio & $-0.00032^{* *}$ & - \\
\hline Banking industry - Herfindahl index & $0.47530^{* * *}$ & - \\
\hline Banking industry - loans growth & -0.00386 & - \\
\hline
\end{tabular}


Table 3 | continuation

\begin{tabular}{|l|c|c|}
\hline Banking industry - return on equity & 0.00048 & - \\
\hline Banking industry - price of borrowed funds & $0.02257^{* * *}$ & - \\
\hline Banking industry - average interest rate charged & -0.00331 & -0.00773 \\
\hline Enforcement of contracts - time to resolve insolvency & $0.02483^{*}$ & - \\
\hline Information asymmetry - credit depth of information index & $0.08517^{* * *}$ & - \\
\hline Survey period $-2009 \mathrm{~s}_{2}$ & 0.01647 & 0.00190 \\
\hline Survey period $-2010 \mathrm{~s}_{1}$ & $0.08851^{* *}$ & $0.06360^{*}$ \\
\hline Survey period $-2010 \mathrm{~s}_{2}$ & 0.06625 & 0.05917 \\
\hline Survey period $-2011 \mathrm{~s}_{1}$ & $0.12190^{* * *}$ & $0.06281^{*}$ \\
\hline Survey period $-2011 \mathrm{~s}_{2}$ & $0.12160^{* * *}$ & $0.08522^{* * *}$ \\
\hline Survey period $-2012 \mathrm{~s}_{1}$ & $0.11050^{* * *}$ & $0.09571^{* * *}$ \\
\hline Survey period $-2012 \mathrm{~s}_{2}$ & $0.08962^{* * *}$ & $0.12300^{* * *}$ \\
\hline Survey period $-2013 \mathrm{~s}_{1}$ & 0.02873 & $0.10740^{* * *}$ \\
\hline Observations & 63,451 & 63,451 \\
\hline
\end{tabular}

Notes: symbols $\leftrightarrow$ indicate no change, $\downarrow$ decrease and $\uparrow$ increase. subscript $s_{1}$ and $s_{2}$ attached to years indicates first or second part of the year. ${ }^{*} p<0.1 ;{ }^{* *} p<0.05 ;{ }^{* *} p<0.01$. (d) stands for dummy variable. Countries dummies included in the empirical model but marginal effects not reported.

Source: Authors

Figure 2 | Banking Industry Capitalization and Conditional Credit Rejection Probability

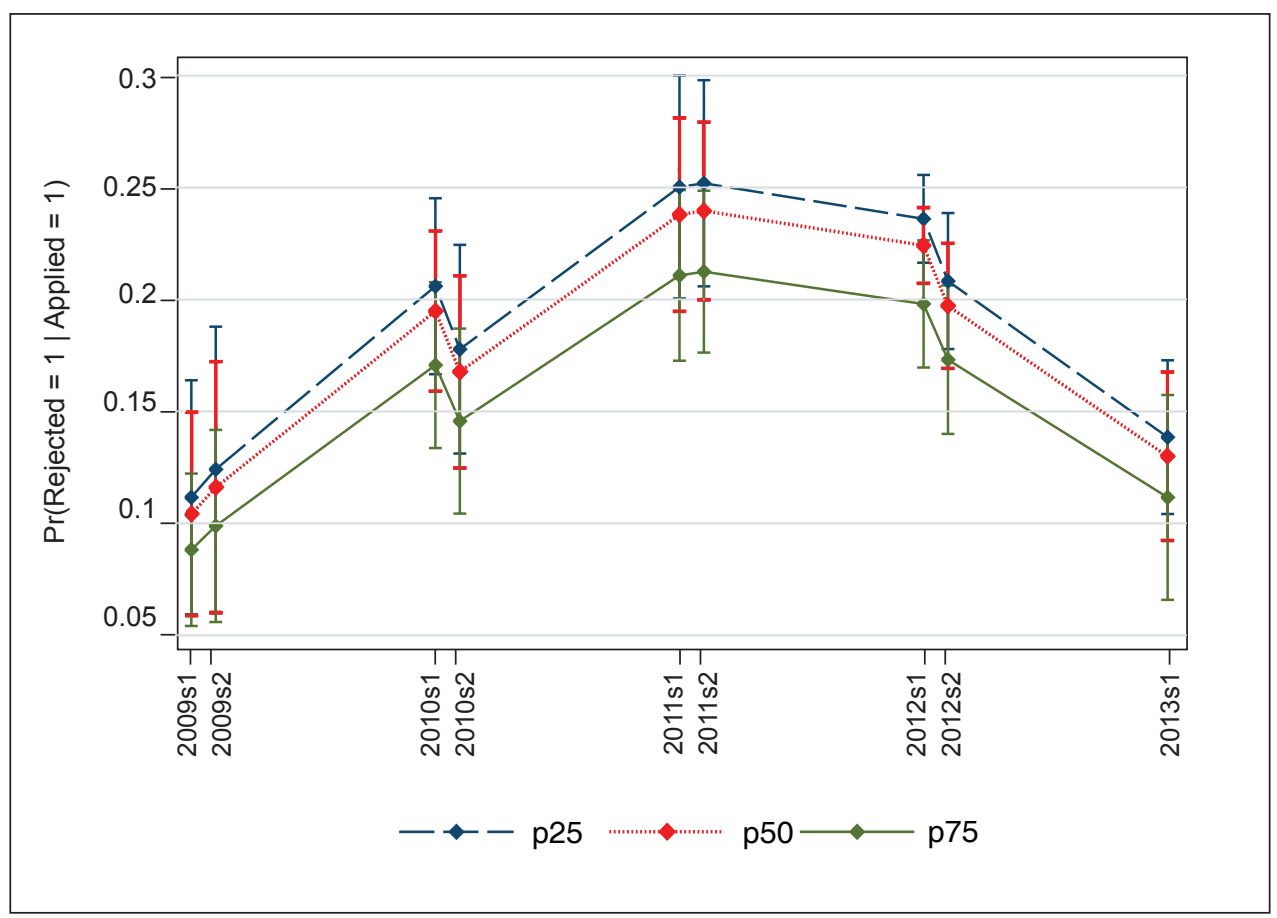

Source: Authors' calculation. Vertical bar above represent lower and upper confidence interval. 
The next set of variables are related to banking sector activities as credit from banks appears to be the main source of funds for SMEs all across the countries irrespective of the stages of development. It is evident from the marginal effects estimates presented in Table 3 that higher capitalization of a bank results in a decrease in rejection probability. A $1 \%$ increase in equity to total assets reduces the rejection probability by $1.3 \%$. Figure 2 shows the relationship between the four percentiles (P25, P50, P75 and P99) of banks' capitalization ratios and the probability of loan application rejection. It is evident throughout the 5-year survey period that better-capitalized banks are likely to support a loan application. Hence, the capitalization of banks not only ensures longer-term survival of the banks but also encourages the intermediary to lend more to small and medium enterprises, in particular during times of financial and economic uncertainty.

Figure 3 | Banking Industry Concentration and Conditional Credit Rejection Probability

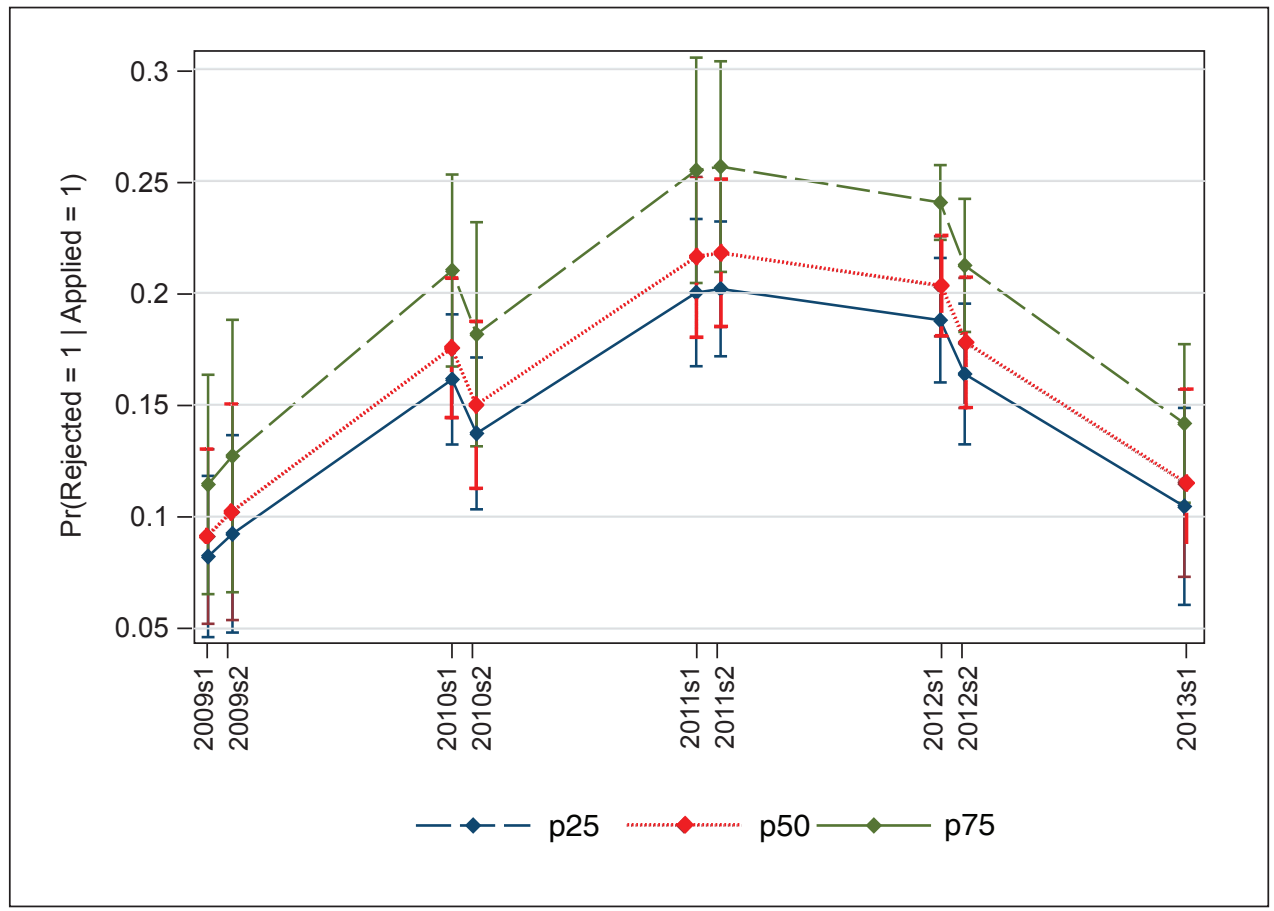

Source: Authors' calculation. Vertical bar above represent lower and upper confidence interval.

Next we test the theoretical models of lending and industrial organization theory, which states that access to finance for firms depends on the market structure. One theory in this regard predicts a positive relation between concentration and credit availability (the information hypothesis) and a second supports the market power hypothesis, in which credit rationing is evident in less competitive banking markets. In our case there appears to be a strong relationship between the structure of the banking industry and the approval 
of loan applications. The marginal-effects estimates show that a decrease in banking market competition results in an increase in credit application rejection probability. Hence, consistent with the market power hypothesis supported by Ryan et al. (2014), our empirical evidence reinforces the notion that higher banking competition promotes lending to SMEs. Figure 3 shows the trend in the conditional rejection probability over different survey periods at four different levels of competition. Countries with a competitive banking industry (with a lower Herfindhal index) have a lower rejection probability (around 10\%) compared with a $40 \%$ probability of rejection in countries with very high concentration levels.

Our empirical estimates also show that an increase in bank funding costs encourages banks to lend less and reject more applications. A 1 percentage point increase in the funding cost increases the rejection probability by more than $2 \%$. Figure 4 shows the trend in the cost of borrowed funds and the application rejection probability. On average, in countries where banks are able to source funds at less than a $1 \%$ interest rate, the credit application rejection probability is $8-10 \%$ compared with a $20-25 \%$ rejection rate in those where the cost of borrowing is more than $4 \%$.

Figure 4 | Banking Industry Cost of Funds and Conditional Credit Rejection Probability

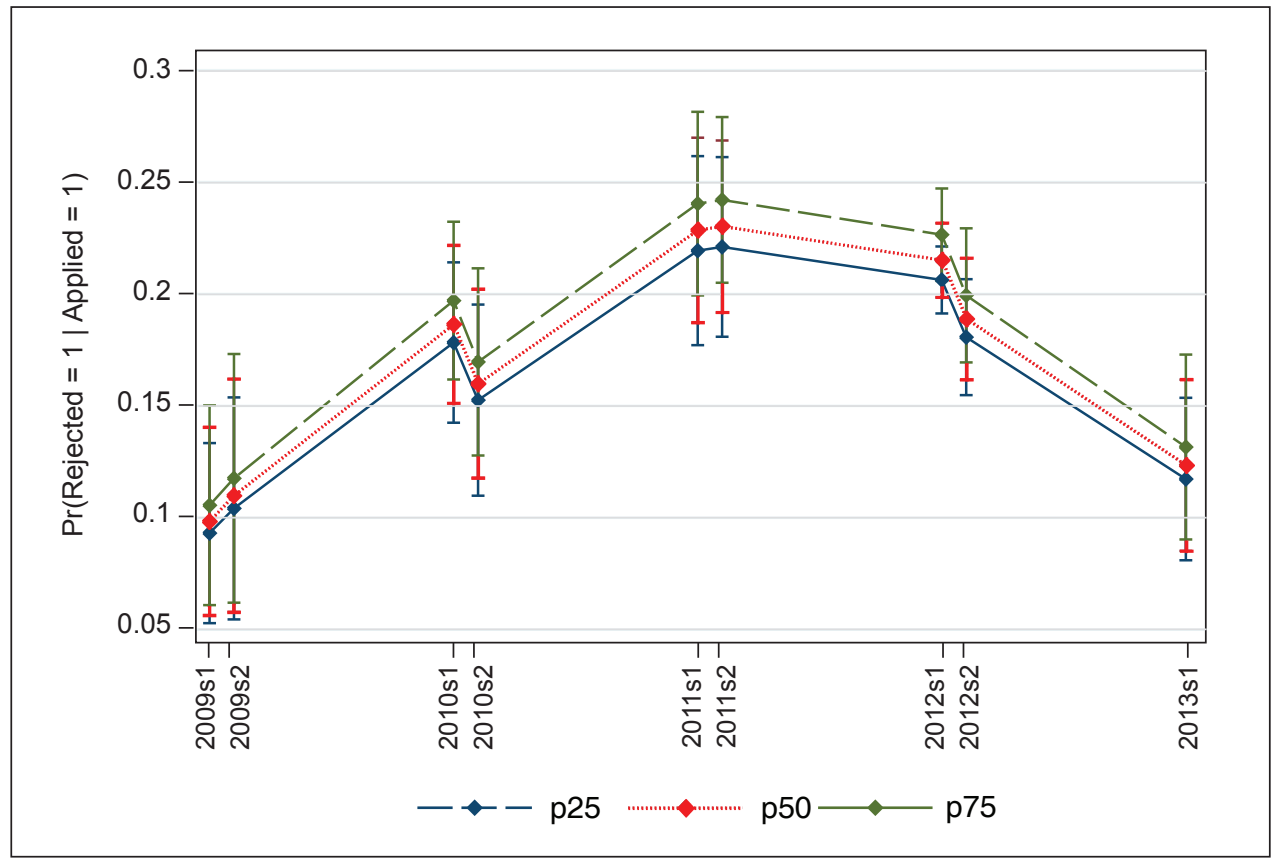

Source: Authors' calculation. Vertical bar above represent lower and upper confidence interval.

The relationship between the qualities of the loan (impaired loans as a percentage of total loans) is approximated by the marginal-effects figure of -0.004 in Table 3 indicating that a $1 \%$ increase would decrease the loan rejection probability by approximately $0.4 \%$. 
Figure 5 shows this relationship more elaborately over the survey periods at four different cut-off points. It appears that more impaired loans would lead to a lower rejection probability. This relationship is observed consistently throughout the sample period. Again, this is a surprising finding given the fact that a higher proportion of bad loans in overall portfolio would compel financial institutions to decrease lending. But perhaps, institutions would prefer to lend to small businesses compared to individuals during times of uncertainty with rising impaired loans. Similar could be said of interbank ratios.

Figure 5 | Banking Industry Impaired Loans and Conditional Credit Rejection Probability

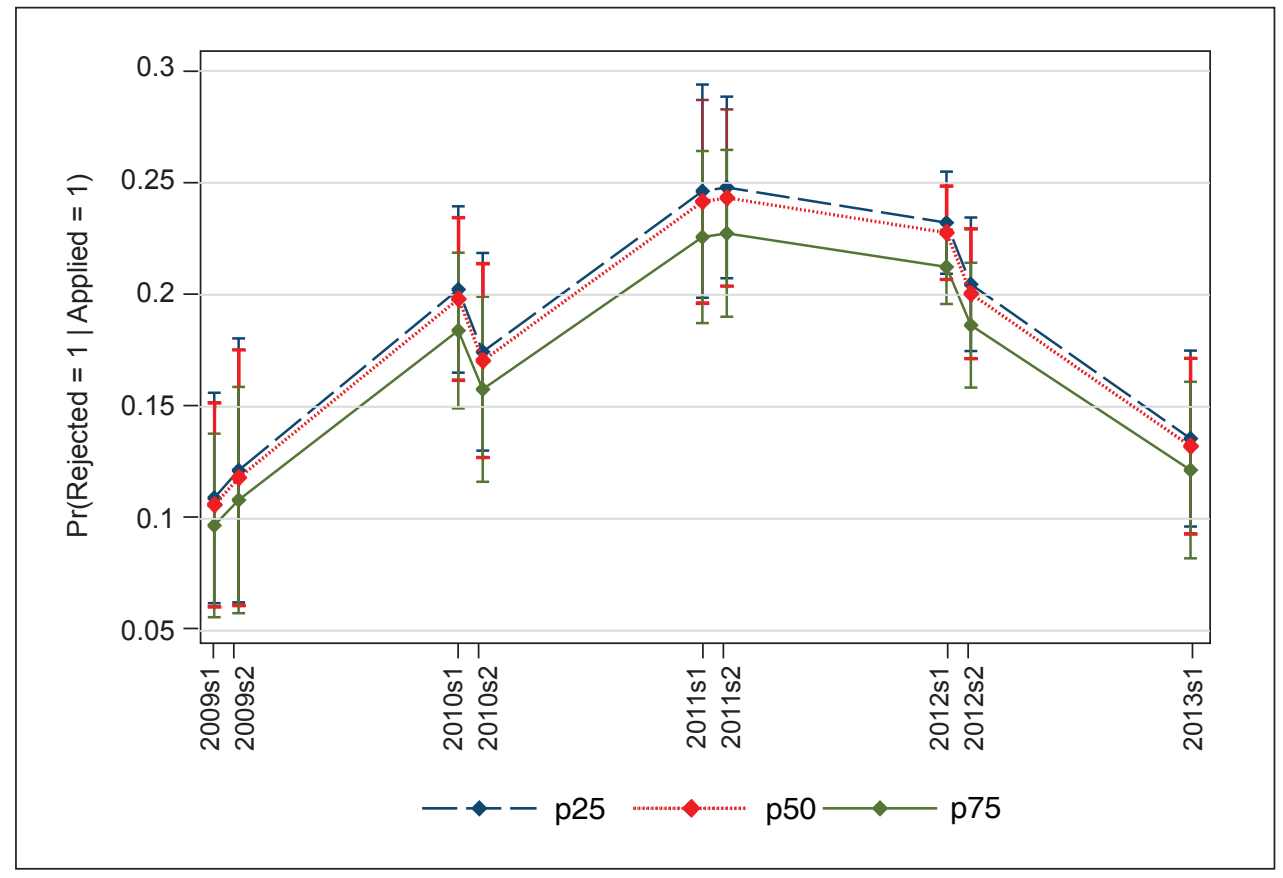

Source: Authors' calculation. Vertical bar above represent lower and upper confidence interval.

One of the significant factors in our determinants of credit rejection modelling is the role of financial information asymmetries as measured by the Credit Depth of Information index (CDI). The CDI scores range from 1 to 6 , where 1 indicates a very low level of sophistication of information sharing and 6, an advanced one. Authors such as Love and Mylenko (2003) and Beck and Demirguc-Kunt (2006) suggest the positive role of credit information sharing in the access to credit. Differing from the above studies, our results in Table 3 show that a 1 point increase in the CDI results in almost $9 \%$ increase in the rejection probability. This relation is also demonstrated in Figure 6. It appears from the trend that improvements in the information flow would lead to banks rejecting more credit requests, probably due to a reduction in the adverse selection issue. This highlights the fact that, when banks and other creditors have to use soft information in the assessment 
of credit applications, it can produce more favourable outcomes for SMEs due to relationship banking. However, hard information compiled through credit information bureaus and rating companies could lead to a higher risk perception. This difference is captured in Figure 6, in which a country with a CDI equal to 2 has a $2-3 \%$ conditional rejection probability compared with a $25-35 \%$ probability if the CDI score is higher.

\section{Figure 6 | Credit Information Depth and Conditional Credit Rejection Probability}

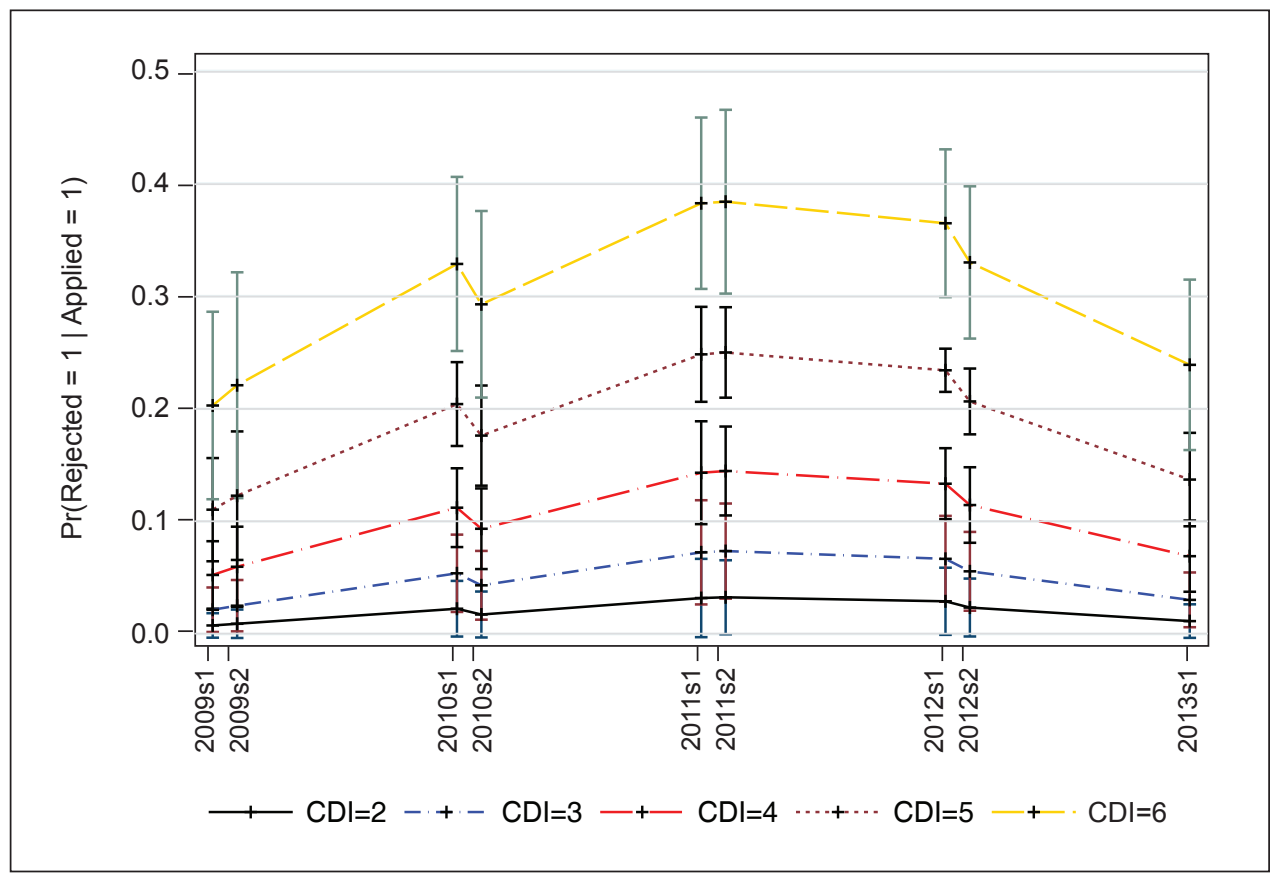

Source: Authors' calculation. Vertical bar above represent lower and upper confidence interval.

Kundid and Ercegovac (2011) argue that a lower cost of entry, a more efficient insolvency procedure and a low cost of contract enforcement encourages SME development. To test the effects of the quality of the legal system, we use the average number of years from filing for insolvency until the settlement of the dispute (this approximates the inefficiency of the legal system). We would expect a positive relationship between time to resolve insolvency and credit application rejection probability. Our marginal-effects estimates confirm this. A 1-year increase in unresolved bankruptcy results in a $2.5 \%$ increase in rejection probability. Figure 7 also shows that on average SMEs operating in countries with advanced and developed systems to deal with bankruptcy have a better chance of obtaining credit from banking and non-banking sources, and this holds true irrespective of the survey time periods. The difference between less than 1 year and more than 3 years to resolve insolvencies seems to be substantial (in fact, on average a 2 times rejection probability with 4 years required to solve the insolvency dispute compared with 1 year). 


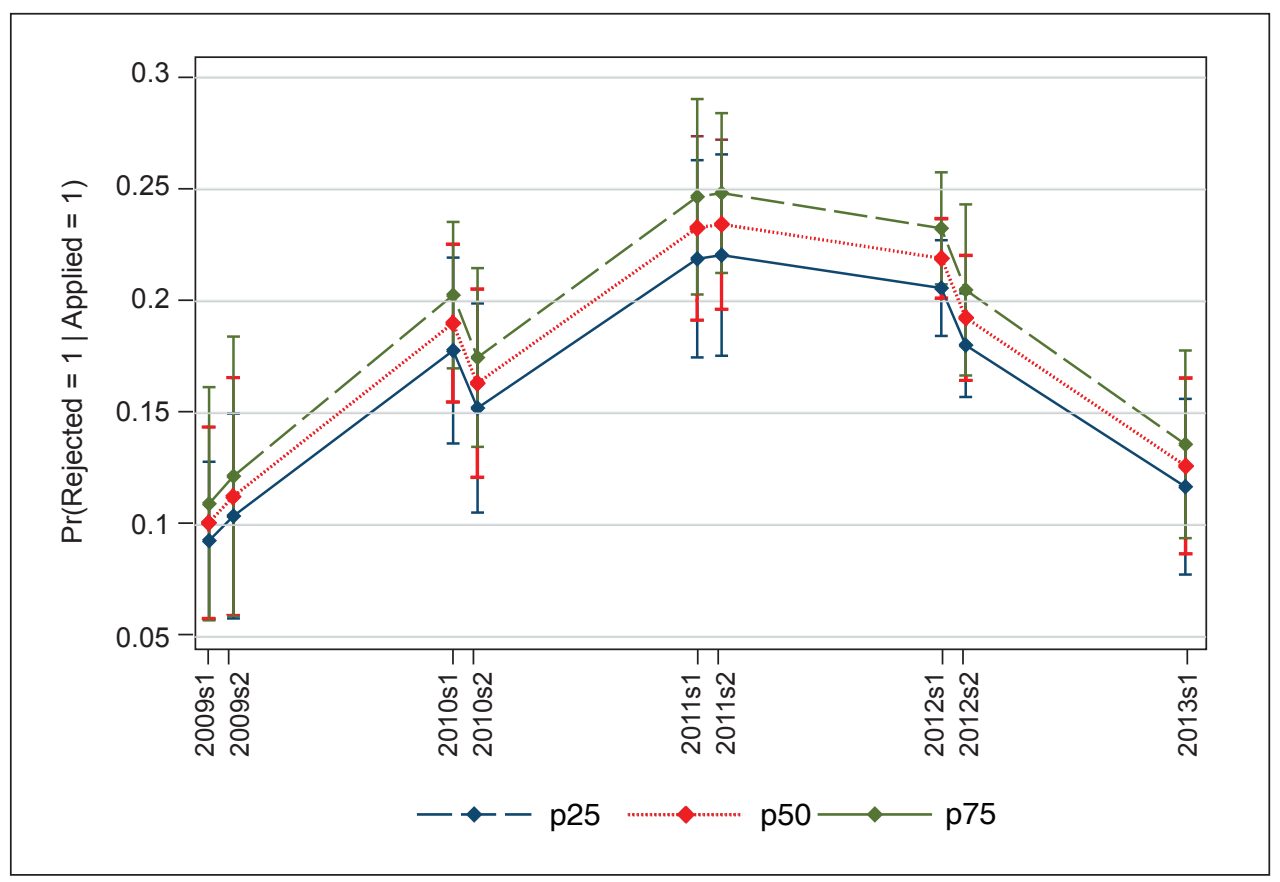

Source: Authors' calculation. Vertical bar above represent lower and upper confidence interval.

Lastly, in an effort to observe the severity of conditions (firm-specific, economic and banking market), we develop and discuss the impact of three different scenarios on the probability of credit application rejection. Based on our marginal-effects estimates, Figure 8 shows three different scenarios: worst, middle and good cases. The conditional predicted probabilities of rejection confirm that the combined effect of macroeconomic, bank-specific and financial environment variables on the allocation of credit is substantial. In particular, in the worst-case scenarios, a firm is small and operates in an environment in which banks are less capitalized and has a high cost of funds, it takes longer to resolve insolvencies, and when credit bureaus are well developed, the probability of credit rejection is $60 \%$ compared with less than $10 \%$ in the middle-case scenario. 


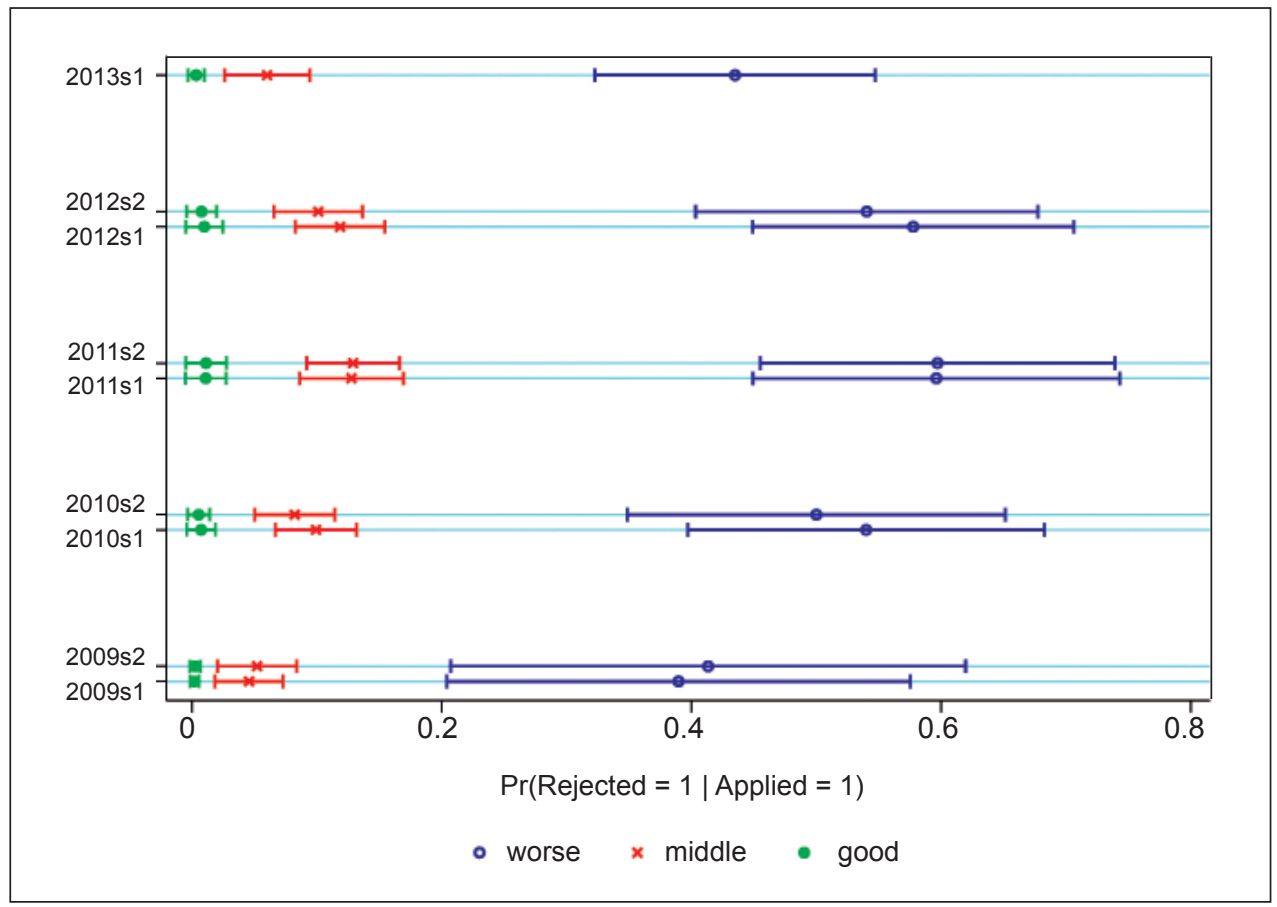

Notes: Worse: small, (p25) equity to assets, (p90) HHI, (p90) time to resolve insolvency, credit depth of information index $=6$, (p90) cost of funds, (p25) impaired loans/gross loans. Middle: large, (p50) equity to assets, (p50) HHI, (p50) time to resolve insolvency, credit depth of information index $=4$, (p50) cost of funds, (p50) impaired loans/gross loans. Good: large, (p90) equity to assets, (p25) HHI, (p25) time to resolve insolvency, credit depth of information index =2, (p25)cost of funds, (p90)impaired loans/gross loans.

Horizontal bar above represent lower and upper confidence interval. The larger bar would indicate significant variations in the rejection probabilities.

Source: Authors' calculation.

\section{Conclusions}

We conclude that access to finance for SMEs in Europe has improved since application rejection probabilities peaked in 2011 and the first half of 2012. Young and small enterprises with a bad credit history, high leverage and a construction sector affiliation are more likely to face hardship in accessing external credit. A competitive and better-capitalized banking industry improves the chance of a credit application being approved. Government support is crucial, as a reduction in this would lead to a higher rejection probability. A case for keeping the interest rate low by the European Central Bank is also made, as an increase in banks' funding cost would lead to increases in credit rejection probabilities. An inefficient legal system that results in a longer time to resolve insolvencies also increases the probability of credit application rejection. Similarly, a reduction in information asymmetries would reduce adverse selection issues and thus could increase the chances of rejection of an SME's credit request. 


\section{References}

Albareto, G., Finaldi Russo, P. (2012). Financial Fragility and Growth Prospects: Credit Rationing during the Crisis. Bank of Italy. Occasional Paper No. 127, https://doi.org/10.2139/ssrn.2159210

Anderson, J., Stallings, J. (2013). Restoring Financing and Growth to Europe's SMEs. Institute of International Finance.

Artola, C., Genre, V. (2011). Euro Area SMEs under Financial Constraints: Belief or Reality? CESifo Monetary Policy and International Finance. Working Paper No. 3650.

Beck, T., Demirgüç-Kunt, A., Laeven, L., Maksimovic, V. (2006). The Determinants of Financing Obstacles. Journal of International Money and Finance, 25(6), 932-952, https://doi. org/10.1016/j.jimonfin.2006.07.005

Beck, T., Demirguc-Kunt, A. (2006). Small and Medium-Size Enterprises: Access to Finance as a Growth Constraint. Journal of Banking and Finance, 30(11), 2931-2943, https://doi. org/10.1016/j.jbankfin.2006.05.009

Beck, T., Demirgüç-Kunt, A., Maksimovic, V. (2008). Financing Patterns around the World: Are Small Firms Different? Journal of Financial Economics, 89(3), 467-487, https://doi. org/10.1016/j.jfineco.2007.10.005

Beck, T., Demirgüç-Kunt, A., Singer, D. (2013). Is Small Beautiful? Financial Structure, Size and Access to Finance. World Development, 52, 19-33, https://doi.org/10.1016/j. worlddev.2013.05.014

Bernanke, B. S., Gertler, M. (1995). Inside the Black Box: the Credit Channel of Monetary Policy Transmission. National Bureau of Economic Research. Cambridge Working Paper No. 5146. https://doi.org/10.3386/w5146

Brown, M., Ongena, S., Popov, A., Yeşin, P. (2011). Who Needs Credit and Who Gets Credit in Eastern Europe? Economic Policy, 26(65), 93-130, https://doi. org/10.1111/j.1468-0327.2010.00259.x

Canales, R., Nanda, R. (2012). A Darker Side to Decentralized Banks: Market Power and Credit Rationing in SME Lending. Journal of Financial Economics, 105(2), 353-366, https://doi. org/10.1016/j.jfineco.2012.03.006

Carbo-Valverde, S., Rodriguez-Fernandez, F., Udell, G. F. (2013). Trade Credit, the Financial Crisis, and SME Access to Finance. 26th Australasian Finance and Banking Conference, https://doi. org/10.2139/ssrn.2307246

Casey, E., O'Toole, C. M. (2014). Bank Lending Constraints, Trade Credit and Alternative Financing during the Financial Crisis: Evidence from European SMEs. Journal of Corporate Finance, 27, 173-193, https://doi.org/10.1016/j.jcorpfin.2014.05.001

Chodorow-Reich, G. (2014). The Employment Effects of Credit Market Disruptions: Firm-Level Evidence from the 2008-9 Financial Crisis. The Quarterly Journal of Economics, 129(1), 1-59, https://doi.org/10.1093/qje/qjt031

Cohen, L. J., Cornett, M. M., Marcus, A. J., Tehranian, H. (2014). Bank Earnings Management and Tail Risk during the Financial Crisis. Journal of Money, Credit and Banking, 46(1), 171-197, https://doi.org/10.1111/jmcb.12101

Cole, R. A., Dietrich, A. (2013). SME Credit Availability around the World: Evidence from the World Bank's Enterprise Surveys. Midwest Finance Association 2013 Annual Meeting Paper, https://doi.org/10.2139/ssrn.2043624 Available at: http://world-finance-conference.com/ papers_wfc2/751.pdf

Hall, R. E. (2014). Quantifying the Lasting Harm to the US Economy from the Financial Crisis. NBER. Macroeconomics Annual, 29, University of Chicago Press, https://doi.org/10.3386/w20183 (?) 
Holton, S., Lawless, M., McCann, F. (2014). Firm Credit in the Euro Area: A Tale of Three Crises. Applied Economics, 46(2), 190-211.

Ivashina, V., Scharfstein, D. (2010). Bank Lending during the Financial Crisis of 2008. Journal of Financial Economics, 97(3), 319-338, https://doi.org/10.1016/j.jfineco.2009.12.001

Jimenéz, G., Ongena, S., Peydró, J. L., Saurina, J. (2012). Credit Supply versus Demand: Bank and Firm Balance-Sheet Channels in Good and Crisis Times. European Banking Center. Discussion Paper No. 3., https://doi.org/10.2139/ssrn.1980139

Kahle, K. M., Stulz, R. M. (2013). Access to Capital, Investment, and the Financial Crisis. Journal of Financial Economics, 110(2), 280-299, https://doi.org/10.1016/j.jfineco.2013.02.014

Kundid, A., Ercegovac, R. (2011). Credit Rationing in Financial Distress: Croatia SMEs' Finance Approach. International Journal of Law and Management, 53(1), 62-84, https://doi. org/10.1108/17542431111111890

Love, I., Mylenko, N. (2003). Credit Reporting and Financing Constraint. World Bank Mimeo. Working Paper No. 3142, https://doi.org/10.1596/1813-9450-3142 Available at: http:// siteresources.worldbank.org/DEC/Resources/Credit_Reporting_and_Financing_ Constraints.pdf

Mac an Bhaird, C. (2013). Demand for Debt and Equity before and after the Financial Crisis. Research in International Business and Finance, 28, 105-117, https://doi.org/10.1016/j. ribaf.2012.10.001

Martínez-Sola, C., García-Teruel, P., Martínez-Solano, P. (2014). Trade Credit and SME Profitability. Small Business Economics, 42(3), 561-577, https://doi.org/10.1007/s11187-013-9491-y

Mishkin, F. S. (1995). Symposium on the Monetary Transmission Mechanism. The Journal of Economic Perspectives, 9(4), 3-10, https://doi.org/10.1257/jep.9.4.3

Modina, M., Pietrovito, F. (2014). A Default Prediction Model for Italian SMEs: the Relevance of the Capital Structure. Applied Financial Economics, 24(23), 1537-1554, https://doi.org/1 0.1080/09603107.2014.927566

Ogawa, K., Tanaka, T. (2013). The Global Financial Crisis and Small- and Medium-Sized Enterprises in Japan: How Did they Cope with the Crisis? Small Business Economics, 41(2), 401-417, https://doi.org/10.1007/s11187-012-9434-z

Peek, J., Rosengren, E. S. (1995). Is Bank Lending Important for the Transmission of Monetary Policy? An Overview. New England Economic Review, 3-10.

Psillaki, M., Daskalakis, N. (2009). Are the Determinants of Capital Structure Country or Firm Specific? Small Business Economics, 33(3), 319-333, https://doi.org/10.1007/ s11187-008-9103-4

Ryan, R. M., O'Toole, C. M., McCann, F. (2014). Does Bank Market Power Affect SME Financing Constraints? Journal of Banking \& Finance, 49, 495-505, https://doi.org/10.1016/j. jbankfin.2013.12.024

Shen, Y., Shen, M., Xu, Z., Bai, Y. (2009). Bank Size and Small- and Medium-Sized Enterprise (SME) Lending: Evidence from China. World development, 37(4), 800-811, https://doi. org/10.1016/j.worlddev.2008.07.014

Tagkalakis, A. (2013). The Effects of Financial Crisis on Fiscal Positions. European Journal of Political Economy, 29, 197-213, https://doi.org/10.1016/j.ejpoleco.2012.11.002

Vermoesen, V., Deloof, M., Laveren, E. (2013). Long-Term Debt Maturity and Financing Constraints of SMEs during the Global Financial Crisis. Small Business Economics, 41(2), 433-448, https://doi.org/10.1007/s11187-012-9435-y 